УДК 621.643.001:536.2

\title{
ВЛИЯНИЕ РАДИАЦИОННОГО ТЕПЛООБМЕНА НА ИНТЕНСИФИКАЦИЮ ТЕПЛОПЕРЕНОСА В ТОНКОПЛЕНОЧНОЙ ТЕПЛОВОЙ ИЗОЛЯЦИИ
}

\author{
Половников Вячеслав Юрьевич, \\ polov@tpu.ru \\ Национальный исследовательский Томский политехнический университет, \\ Россия, 634050, г. Томск, пр. Ленина, 30.
}

\begin{abstract}
Актуальность исследования обусловлена тем, что тепловая защита оборудования и трубопроводов играет важную роль при проведении энергосберегающих мероприятий на энергетических объектах различного назначения, а рост уровня потерь тепла или холода при транспортировке энергоносителей является причиной создания новых подходов к энергосберегающим мероприятиям при выполнении теплоизоляционных работ. Известно, что основным методом снижения потерь тепловой энергии при ее транспортировке и хранении является применение высокоэффеективных теплоизоляционных материалов. Таким материалом является тонкопленочная тепловая изоляция. Уникальные теплофизические характеристики тонкопленочных теплоизоляционных покрытий позволяют использовать их в различных энергетических системах и оборудовании. Несмотря на это технологии применения тонкопленочных теплоизоляционных покрытий к настоящему моменту времени не получили развития. Это объясняется рядом причин, основными из которых являются: недостаток знаний о физических свойствах и механизмах процессов тепломассопереноса в тонкопленочных теплоизоляционных покрытиях.

Цель: исследование кондуктивно-конвективно-радиационного теплопереноса в слое тонкопленочной тепловой изоляции с учетом разнородности свойств микросфрер и связующих веществ.

Объект: иилиндрический слой тонкопленочного теплоизоляционного покрытия. На внутренней и внешней поверхностях теплоизоляционного покрытия поддерживаются постоянные температуры. Геометрия тонкопленочного теплоизоляционного покрытия представляла собой связующее вещество и полые микросфееры. Исследования проводились для слоя теплоизоляции толщиной 0,33 мм. Температура на внутренней и внешней поверхностях изоляции принималась в соответствии $c$ экспериментальными данными. Предполагалось, что слой тонкопленочной теплоизоляции на 62 \% состоит из микросфрер диаметром 50 мкм и на 38 \% из связующего вещества. Рассматривались два типа польх микроссфер с толщинами стенок: 5 и 2 мKM.

Методы. Решение поставленной задачи получено методом конечных элементов. Использовалась аппроксимация Галеркина, неравномерная конечно-элементная сетка. Параметры элементов сетки выбирались из условий сходимости решения. Увеличение числа элементов расчетной сетки проводилось с использованием метода Делоне.

Результаты. Установлены величины тепловых потоков в слое тонкопленочной тепловой изоляции при наличии радиационного теплообмена. На основании сопоставления результатов численного моделирования теплопереноса в слое тонкопленочной тепловой изоляции, выполненного с использованием кондуктивно-конвективной модели теплопереноса, с результатами для кондуктивно-конвективно-радиационной модели установлено, что расхождение между ними не превышает 0,1 \% и объясняется погрешностями численных расчетов. По этой причине в практических расчетах можно использовать более простую кондуктивную модель теплопереноса.
\end{abstract}

\section{Ключевые слова:}

Тонкопленочная тепловая изоляция, энергосбережение, теплоснабжение, транспортировка и хранение энергии, моделирование.

\section{Введение}

Энергетическая стратегия и программы повышения энергоэффективности промышленности и сельского хозяйства регионов РФ тесно связаны с энергосбережением в различных отраслях. Одной из них является энергоснабжение.

Системы транспортировки и хранения энергоносителей могут стать источником значительной экономии ресурсов за счет снижения уровня тепловых потерь. Существенно снизить масштабы потерь тепловой энергии при транспортировке и хранении можно только используя современные научно-обоснованные подходы к энергосберегающим мероприятиям в этих системах.

Известно, что основным методом снижения потерь тепловой энергии при ее транспортировке и хранении является использование теплоизоляционных материалов [1-4], отвечающих современным требованиям. Подобными материалами являются тонкопленочные теплоизоляционные материалы $[5,6]$.
Исследованиям теплопереноса в слое тонкопленочной тепловой изоляции и эффективности ее применения посвящено достаточное количество работ [5-20]. В них рассматриваются технология использования теплозащитных светопропускающих тонкопленочных покрытий [7-11], кондуктивный теплоперенос в слое тонкопленочной тепловой изоляции $[6,12$, 13], а также различные практические приложения [14-20], в которых учитывается влияние условий эксплуатации тонкопленочной тепловой изоляции на уровень тепловых потерь оборудования и трубопроводов.

Учет комплекса основных взаимосвязанных факторов и процессов, приводящих к интенсификации тепловых потерь, при моделировании тепловых режимов систем транспортировки и хранения энергоносителей позволяет дать более детализированный прогноз тепловых состояний рассматриваемых объектов.

Исследования [6] показали, что теплоперенос в газонаполненных полостях микросфер может осу- 
ществляться за счет теплопроводности, конвекции и лучистого теплообмена. В современной научной литературе [1-20] отсутствует описание влияния механизмов теплопереноса в тонкопленочных теплоизоляционных покрытиях на интенсификацию тепловых потерь энергетического оборудования. По этой причине необходимым является исследование сопряженного кондуктивно-конвективно-радиационного теплопереноса в рассматриваемой системе.

Ограниченность энергосберегающих мероприятий с применением тонкопленочной тепловой изоляции объясняется не только отсутствием нормативной базы, но и в большей степени проблемами, связанными с проектированием энергоэффективных теплопроводов, поскольку в настоящее время отсутвует единая методика создания энергосберегающих систем транспортировки и хранения тепловой энергии с использованием тонкопленочной тепловой изоляции.

Целью работы является исследование сопряженного кондуктивно-конвективно-радиационного теплопереноса в тонкопленочном теплоизоляционном покрытии.

\section{Постановка задачи}

Рассматривается слой тонкопленочного теплоизоляционного покрытия, состоящего их полых микросфер и связующего вещества. На поверхностях тонкопленочного изоляционного покрытия выставляются граничные условия первого рода. На рисунке схематично представлена область для решения задачи. Для этой области (рисунок) была решена задача, учитывающая сопряженный теплоперенос в системе «полые микросферы - связующее вещество». Использование подхода такого рода к решаемой задаче обосновано в [21], поскольку из анализа размерных эффектов в проблемах переноса тепла [22] известно, что нижней границей применения уравнений Навье-Стокса и законов теплопереноса Фурье и Ньютона-Рихмана является размер не менее 100 нм.

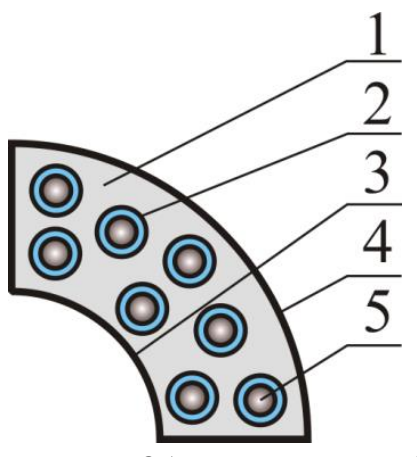

Рисунок. Область решения задачи: 1 - связующее вещество; 2 - стенка микросферы; 3 - внутренняя поверхность изолячии; 4 - внешняя поверхность изоляции; 5 - полость микросферь

Figure. Scheme of solution area: 1-binder; 2 - surface of microspheres; 3 - inner surface of insulation; 4 outer surface of insulation; 5 -microsphere cavity

Основные допущения, при которых решена задача, состоят в следующем:
1. Теплофизические свойства являются известными и постоянными величинами. Диапазон изменения параметров, влияющих на теплофизические характеристики, в рассматриваемой задаче невелик [23], следовательно, изменением свойств можно пренебречь.

2. Газ в микросферах является несжимаемой средой и удовлетворяет приближению Буссинеска [24].

3. Микросферы являются унифицированными по размеру и в слое изоляции располагаются упорядоченно («коридорное» размещение).

4. На границах контакта между элементами рассматриваемой системы имеет место условие идеального теплового контакта.

5. На внутренней и внешней поверхностях тонкопленочной тепловой изоляции выставляются граничные условия первого рода (условия эксперимента, описанного в [6]).

6. Скорость газа на внутренней поверхности стенок микросфер равна нулю (условие прилипания).

Принятые допущения, с одной стороны, не накладывают принципиальных ограничений на физическую модель системы, а с другой - позволяют упростить алгоритм и метод решения поставленной задачи.

\section{Математическая модель}

Математическая постановка задачи имеет вид:

$$
\begin{gathered}
C_{i, 5} \rho_{i, 5}\left(\vec{w}_{i, 5}, \nabla T_{i, 5}\right)=\lambda_{i, 5} \nabla^{2} T_{i, 5}, i=1-n, \\
\left(\vec{w}_{i, 5}, \nabla\right) \overrightarrow{w_{i, 5}}=-\frac{1}{\rho_{i, 5}} \nabla p_{i, 5}+v_{i, 5} \nabla^{2} \vec{w}_{i, 5}+\vec{F}, i=1-n, \\
\nabla \vec{w}_{i, 5}=0, i=1-n \\
\nabla^{2} T_{1}=0, \\
\nabla^{2} T_{i, 2}=0, i=1-n, \\
T_{i n s, 3}=T_{i n}=\text { const, } \\
T_{i n s, 4}=T_{e x}=\text { const, } \\
\lambda_{1} \operatorname{grad}\left(T_{1}\right)=\lambda_{2} \operatorname{grad}\left(T_{i, 2}\right), T_{1}=T_{i, 2}, i=1-n \\
\lambda_{2} \operatorname{grad}\left(T_{2}\right)=\lambda_{5} \operatorname{grad}\left(T_{i, 5}\right)+\varepsilon \sigma\left[T_{2}^{4}-T_{i, 5}^{4}\right], i=1-n, \\
\operatorname{grad}\left(T_{i, 2}\right)=0, i=1-n, \\
w_{i, 5}=0, i=1-n \\
F_{y}=G \beta_{i, 5}\left(T_{4}-T_{3}\right), i=1-n
\end{gathered}
$$

Обозначения: $C$ - теплоемкость; $F$ - массовые силы; $G$ - ускорение силы тяжести; $T$ - температура; $p-$ давление; $w$ - скорость; $\beta$ - коэффициент температурного расширения; $\lambda$ - коэффициент теплопроводности; $v$ - кинематическая вязкость; $\rho$ - плотность; $\varepsilon$ - приведенная степень черноты; $\sigma$ - постоянная СтефанаБольцмана.

Индексы: 1-5 - в соответствии с рисунком; ex внешний; ins - изоляция; in - внутренний; $n$ - количество микросфер, шт. 


\section{Метод решения и исходные данные}

Задача (1)-(13) решена с использованием метода конечных элементов [25] с применением неравномерной конечно-элементной сетки.

Моделирование выполнено для теплоизоляционного покрытия, толщина которого составляла 0,33 мм. Покрытие на 62 \% состоит из микросфер со следующими геометрическими характеристиками: диаметр 50 мкм, толщина стенок: 5 и 2 мкм.

Исследования проводились при значениях теплофизических характеристик рассматриваемой системы (рисунок), описанных в [6], а приведенная степень черноты составляла 0,8 [26]. Значения температур на поверхностях слоя изоляции принимались по данным экспериментов [6] и составляли $T_{i n}=363,15 \mathrm{~K}$, $T_{e x}=359,49 \mathrm{~K}$.

\section{Результаты численного моделирования}

В таблице представлены значения линейных тепловых потоков от трубопровода, изолированного тонкопленочным покрытием для кондуктивноконвективной $Q_{1}$, кондуктивной $Q_{2}$ [6] и кондуктивно-конвективно-радиационной $Q_{3}$ моделей, а также приведено сопоставление результатов численного моделирования и экспериментальных исследований $(Q=27,09$ Вт/м [6]).

По результатам численного моделирования установлено, что структура движения газовой среды в полостях микросфер тонкопленочного теплоизоляционного покрытия представляет собой замкнутые циркуляционные течения (максимальная скорость не превышает $7 \cdot 10^{-4} \mathrm{M} / \mathrm{c}$ ), а разности температур на границах микросфер составляют не более $0,4 \mathrm{~K}$.

Анализ результатов математического моделирования (таблица) позволяет сделать следующие ожидаемые заключения:

- отклонение результатов численного моделирования от данных экспериментальных исследований $Q$ является значительным (до $70 \%$ ) и зависит от состава тонкопленочного теплоизоляционного покрытия;

- сравнение результатов численного анализа тепловых потоков в тонкопленочном теплоизоляционном покрытии $Q_{1}$ и $Q_{2}$ [6] позволяет сделать вывод о том, что отклонение между ними составляет не более 3 \% и может быть объяснено погрешностями численных расчетов;

- отклонение $Q_{1}$ (кондуктивно-конвективная модель) от $Q_{3}$ (кондуктивно-конвективно-радиационная модель) не превышает $0,1 \%$ и объясняется несущественными разностями температур на границах микросфер.

По этим причинам для практических расчетов можно использовать более простую модель [6].

Таблица. Результаты численного моделирования

Table. Results of numerical simulation

\begin{tabular}{|c|c|c|c|c|c|c|c|c|c|}
\hline \multirow{2}{*}{\multicolumn{4}{|c|}{$\begin{array}{l}\text { Состав тонкопленочного теплоизоляционного покрытия } \\
\text { Composition of the thin-film insulation coating }\end{array}$}} & $Q_{1}$ & $Q_{2}[6]$ & $Q_{3}$ & \multirow{2}{*}{$\frac{Q_{2}-Q_{1}}{Q_{2}} 100 \%$} & \multirow{2}{*}{$\frac{Q-Q_{2}}{Q} 100 \%$} & \multirow{2}{*}{$\frac{Q_{1}-Q_{3}}{Q_{1}} 100 \%$} \\
\hline & & & & & $\mathrm{T} / \mathrm{m} / \mathrm{W} /$ & & & & \\
\hline \multirow{8}{*}{ 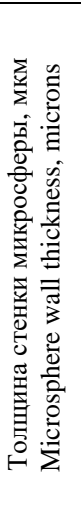 } & \multirow{4}{*}{5} & \multirow{2}{*}{$\begin{array}{l}\text { Воздух } \\
\text { Air }\end{array}$} & $\begin{array}{l}\text { Трехкомпонентное связующее } \\
\text { Three-component binder }\end{array}$ & 51,00 & 52,08 & 50,98 & 2,07 & 47,91 & 0,04 \\
\hline & & & $\begin{array}{l}\text { Однокомпонентное связующее } \\
\text { Single component binder }\end{array}$ & 74,24 & 75,36 & 74,23 & 1,49 & 65,7 & 0,01 \\
\hline & & \multirow{2}{*}{$\mathrm{CO} 2+\mathrm{N} 2$} & $\begin{array}{c}\text { Tрехкомпонентное связующее } \\
\text { Three-component binder } \\
\end{array}$ & 52,92 & 54,12 & 52,89 & 2,21 & 49,83 & 0,04 \\
\hline & & & $\begin{array}{l}\text { Однокомпонентное связующее } \\
\text { Single component binder }\end{array}$ & 76,15 & 74,92 & 76,14 & $-1,64$ & 65,51 & 0,01 \\
\hline & \multirow{4}{*}{2} & \multirow{2}{*}{$\begin{array}{l}\text { Воздух } \\
\text { Air }\end{array}$} & $\begin{array}{c}\text { Tрехкомпонентное связующее } \\
\text { Three-component binder } \\
\end{array}$ & 29,56 & 29,89 & 29,54 & 1,11 & 9,36 & 0,08 \\
\hline & & & $\begin{array}{c}\text { Однокомпонентное связующее } \\
\text { Single component binder } \\
\end{array}$ & 48,58 & 47,33 & 48,57 & $-2,65$ & 45,4 & 0,02 \\
\hline & & \multirow{2}{*}{$\mathrm{CO} 2+\mathrm{N} 2$} & $\begin{array}{c}\text { Трехкомпонентное связующее } \\
\text { Three-component binder } \\
\end{array}$ & 33,85 & 33,08 & 33,84 & $-2,34$ & 17,9 & 0,02 \\
\hline & & & $\begin{array}{l}\text { Однокомпонентное связующее } \\
\text { Single component binder }\end{array}$ & 46,12 & 46,60 & 46,08 & 1,03 & 44,31 & 0,09 \\
\hline
\end{tabular}

\section{Заключение}

Впервые проведено исследование кондуктивноконвективно-радиационного теплопереноса в тонкопленочном теплоизоляционном покрытии.

В работе показано, что высокая степень детализации анализа основных теплофизических процессов, протекающих в слое тонкопленочной тепловой изоляции теплотрубопроводов, создает объективные

\section{СПИСОК ЛИТЕРАТУРЫ}

1. Optimization modeling for smart operation of multi-source district heating with distributed variable-speed pumps / H. Wang, H. Wang, Zh. Haijian, T. Zhu // Energy. - 2017. - V. 138. - P. 1247-1262. предпосылки для более качественного прогноза их тепловых потерь и тепловых режимов.

По результатам исследований показано, что для практических расчетов можно использовать простую кондуктивную модель [6].

Исследование выполнено при финансовой поддержке РФФИ в рамках научного проекта № 18-48-700008-р_а.

2. Половников В.Ю. Тепловые режимы и тепловые потери подземных трубопроводов с учетом реальных условий теплообмена на внешнем контуре взаимодействия // Известия Томского политехнического университета. Инжиниринг георесурсов. - 2018. - T. 329. - № 1. - C. 124-131. 
3. Thermal transient prediction of district heating pipeline: optimal selection of the time and spatial steps for fast and accurate calculation / Y. Wanga, S. Youa, H. Zhanga, X. Zhenga, W. Zhenga, Q. Miaoa, G. Luc // Applied Energy. - 2017. V. 206. - P. 900-910

4. Селиванова 3.М., Павлов В.И. Интеллектуальная информационно-измерительная система теплофизических свойств теплоизоляционных покрытий магистральных трубопроводов // Известия Томского политехнического университета. Инжиниринг георесурсов. - 2019. - Т. 330. - № 10. - С. 145-154.

5. Choice and optimization of ratio of components to develop fastmounted thermostable heat-insulating constructions / N.A. Loginova, S.V. Grigorev, E.E. Lapin, S.I. Pogorelov, A.V. Ryzhenkov // Thermal Engineering. - 2016. - V. 63 (5). P. $355-359$.

6. Половников В.Ю. Кондуктивный теплоперенос в слое тонкопленочной тепловой изоляции // Известия Томского политехнического университета. Инжиниринг георесурсов. - 2019. T. 330. - № 5. - C. 189-197.

7. Chou H.M., Chen C.R., Wu T.N. New transparent thin films for thermal insulation // Journal of the Chinese Society of Mechanical Engineers. Transactions of the Chinese Institute of Engineers Series C. - 2015. - V. 36 (1). - P. 85-90.

8. The evaluation of energy saving using ultrathin heat insulation in railway electrification substation / H. Kim, J. Jang, S. Shin, Y. Park, S. Kim, H.R. Kim, B. Hyun, J. Kim // Transactions of the Korean Institute of Electrical Engineers. - 2015. - V. 64 (1). - P. 171-175.

9. Qi Y., Yin X., Zhang J. Transparent and heat-insulation plasticized polyvinyl chloride (PVC) thin film with solar spectrally selective property // Solar Energy Materials and Solar Cells. - 2016. V. 151. - P. 30-35.

10. Patankar S.N., Kranov Y.A. Hollow glass microsphere HDPE composites for low energy sustainability // Materials Science and Engineering. - 2010. - V. 527. - P. 1361-1366.

11. Effect of hollow glass microsphere thin film on heat-insulation performance of building envelope / H. Wang, H.J. Fang, Q.D. Lan, S. He, C. Jiang // Shanghai Jiaotong Daxue Xuebao/Journal of Shanghai Jiaotong University. - 2014. - V. 48 (9). - P. 1341-1345.

12. Thermal conductivity of powder silica hollow spheres / Y. Liao, X. Wua, H. Liua, Y. Chen // Thermochimica Acta. - 2011. V. 526. - P. 178-184.

13. Numerical analyses of the thermal conductivity of random hollow sphere structures / T. Fiedler, R. Löffler, T. Bernthaler, R. Winkler, I.V. Belova, G.E. Murch, A. Öchsnerc // Materials Letters. 2009. - V. 63. - № 13-14. - P. 1125-1127.

14. Evaluation of the thermal efficiency of a high-temperature heatinsulation structure based on honeycomb plastic / A.V. Ryzhenkov,
E.E. Lapin, N.A. Loginova, D.R. Sitdikov, S.V. Grigorev // Thermal Engineering. - 2016. - V. 63 (6). - P. 445-448.

15. Investigation of heat capacity of syntactic foam based on silicone and organic matrix / E.V. Belyaeva, N.A. Loginova, E.E. Lapin, S.I. Pogorelov, A.V. Ryzhenkov // Oil Industry. - 2016. - № 11. P. 116-119.

16. Study of the influence of the modification of glass microspheres on the properties of syntactic foams based on oligomethylsiloxane / V.S. Osipchik, N.V. Kostromina, Y. Olikhova, V.N. Ivashkina, E.V. Belyaeva, N.A. Loginova, A.V. Ryzhenkov, E.E. Lapin // International Polymer Science and Technology. - 2016. V. 43 (7). - P. 133-137.

17. Study of relations components for making flexible polymer insulation with optimum thermal and mechanical characteristics / S.V. Levitin, E.V. Belyaeva, N.A. Loginova, E.E. Lapin, A.V. Ryzhenkov // Oil Industry. - 2015. - № 9. - P. 130-133.

18. Review of binding agents in syntactic foams for heat-insulating structures in power industry Facilities / A.V. Ryzhenkov, N.A. Loginova, E.V. Belyaeva, Y.Y. Lapin, A.F Prischepov // Modern Applied Science - 2015. - V. 9. - № 4. - P. 96-105.

19. Polovnikov V.Y., Chuiko N.S. Heat transfer in layer of thin-film thermal insulation // AIP Conference Proceedings. - 2019. V. 2135. - P. 020045-1-020045-3.

20. Kudryakov O.V., Varavka V.N. Integrated indentation tests of metal-ceramic nanocomposite coatings // Inorganic Materials. 2015. - V. 51. - № 15. - P. 1508-1514.

21. Zhang Z. Nano/microscale heat transfer. - New York: McGrawHill, 2007. - $479 \mathrm{p}$.

22. Flik M., Choi B., Goodson K. Heat transfer regimes in microstructures // Journal Heat Transfer. - 1992. - V. 114. P. 667-674.

23. Bynum R.T. Insulation Handbook. - New York: McGraw-Hill, 2001. $-494 \mathrm{p}$

24. Bejan A. Convection heat transfer. - New York: Wiley, 2004. $696 \mathrm{p}$

25. Garcia A.L. Numerical methods for physics. - San Jose CA: CreateSpace Independent Publishing Platform, 2015. - 432 c.

26. Экспериментальное определение интегральной степени черноты сверхтонких жидких композиционных теплоизолирующих покрытий / М.В. Анисимов, Д.В. Лычагин, В.С. Рекунов, Ж.Т. Таалайбеков // Известия Томского политехнического университета. Инжиниринг георесурсов. - 2016. - Т. 327. № 5. - C. 106-115.

Поступила 13.03.2020 2.

\section{Информация об вторах}

Половников В.Ю., кандидат технических наук, доцент Инженерной школы энергетики Национального исследовательского Томского политехнического университета. 
UDK 621.643.001:536.2

\title{
INFLUENCE OF RADIATION HEAT EXCHANGE ON HEAT TRANSFER INTENSIFICATION IN THIN-FILM THERMAL INSULATION
}

\author{
Viacheslav Yu. Polovnikov, \\ polov@tpu.ru \\ National Research Tomsk Polytechnic University, \\ 30, Lenin avenue, Tomsk, 634050, Russia.
}

\begin{abstract}
The relevance of the study is explained by the fact that thermal protection of equipment and pipelines is important when implementing energy-saving measures at energy facilities for various purposes. The increase in heat or cold losses during the transportation of energy carriers is the reason for creating new approaches to energy-saving measures when performing thermal insulation actions. The main method of reducing heat energy losses during its transportation and storage is the use of highly efficient thermal insulation materials. This material is thin-film thermal insulation. The unique thermal characteristics of thin-film thermal insulation coatings are the reason for their use in various energy systems and equipment. Despite this, the technology of using thin-film insulating coatings has not been developed. This is due to the following reasons: lack of knowledge about the physical properties and mechanisms of heat and mass transfer in thinfilm thermal insulation coatings.

The main aim of the research is a study of conductive-convective-radiation heat transfer in the layer of thin-film thermal insulation taking into account the heterogeneity of the properties of the microspheres and binders.

The object of the research is a cylindrical layer of thin-film insulating coating. The temperature is constant on the inner and outer surfaces of the thermal insulation coating. The geometry of the thin-film thermal insulation coating was a binder and hollow microspheres. Scientific research was carried out for a layer of insulation thickness of 0,33 $\mathrm{mm}$. The temperatures on the inner and outer surfaces of the insulation were taken in accordance with the experimental data. The layer of thin-film thermal insulation for $62 \%$ consists of microspheres with a diameter of 50 microns and for $38 \%$ of binder. Two types of hollow microspheres with wall thicknesses ( 5 and $2 \mu \mathrm{m})$ were considered.

Methods. The solution of the problems posed is obtained by the finite element method. Galerkin approximation, non-uniform finite element mesh were used. The parameters of the grid elements were chosen from the conditions of convergence of the solution. An increase in the number of elements of the computational grid was carried out using the Delaunay method.

Results. The authors established the values of heat fluxes in the layer of thin-film thermal insulation in the presence of radiation heat transfer. Comparison of the results of numerical simulation of heat transfer in a layer of thin-film thermal insulation, performed using a conductive-convective heat transfer model with the results for a conductive-convective-radiation model showed a discrepancy between them does not exceed 0,1\%. This is due to errors in numerical calculations. For this reason, a simpler conductive model of heat transfer can be used in practical calculations.
\end{abstract}

\section{Key words:}

Thin-film thermal insulation, energy saving, heat supply, transportation and storage of energy, modeling.

The research was financially supported by the RFBR within the scientific project no. 18-48-700008-p_a.

\section{REFERENCES}

1. Wang H., Wang H., Haijian Zh., Zhu T. Optimization modeling for smart operation of multi-source district heating with distributed variable-speed pumps. Energy, 2017, vol. 138, pp. 1247-1262.

2. Polovnikov V.Y. Thermal regimes and thermal losses of underground pipelines in real heat exchange on the outer interaction boundary. Bulletin of the Tomsk Polytechnic University Geo Assets Engineering, 2018, vol. 329, no. 1, pp. 124-131. In Rus.

3. Wanga Y., Youa S., Zhanga H., Zhenga X., Zhenga W., Miaoa Q., Luc G. Thermal transient prediction of district heating pipeline: Optimal selection of the time and spatial steps for fast and accurate calculation. Applied Energy, 2017, vol. 206, pp. 900-910.

4. Selivanova Z.M., Pavlov V.I. Intelligent information-measuring system of thermophysical properties of thermal insulation coatings of trunk pipelines. Bulletin of the Tomsk Polytechnic University. Geo Assets Engineering, 2019, vol. 330, no. 10, pp. 145-154. In Rus.

5. Loginova N.A. Grigorev S.V., Lapin E.E., Pogorelov S.I., Ryzhenkov A.V. Choice and optimization of ratio of components to develop fast-mounted thermostable heat-insulating constructions. Thermal Engineering, 2016, vol. 63 (5), pp. 355359.

6. Polovnikov V.Yu. Conductive heat transfer in layer of thin-film thermal insulation. Bulletin of the Tomsk Polytechnic University. Geo Assets Engineering, 2019, vol. 330 (5), pp. 189-197. In Rus.

7. Chou H.M., Chen C.R., Wu T.N. New transparent thin films for thermal insulation. Journal of the Chinese Society of Mechanical
Engineers. Transactions of the Chinese Institute of Engineers. Series C, 2015, vol. 36 (1), pp. 85-90.

8. Kim H., Jang J., Shin S., Park Y., Kim S., Kim H.R., Hyun B., Kim J. The evaluation of energy saving using ultrathin heat insulation in railway electrification substation. Transactions of the Korean Institute of Electrical Engineers, 2015, vol. 64 (1), pp. 171175.

9. Qi Y., Yin X., Zhang J. Transparent and heat-insulation plasticized polyvinyl chloride (PVC) thin film with solar spectrally selective property. Solar Energy Materials and Solar Cells, 2016, vol. 151, pp. 30-35.

10. Patankar S.N., Kranov Y.A. Hollow glass microsphere HDPE composites for low energy sustainability. Materials Science and Engineering, 2010, vol. 527, pp. 1361-1366.

11. Wang H., Fang H.J., Lan Q.D., He S., Jiang C. Effect of hollow glass microsphere thin film on heat-insulation performance of building envelope. Shanghai Jiaotong Daxue Xuebao/Journal of Shanghai Jiaotong University, 2014, vol. 48 (9), pp. 1341-1345.

12. Liao Y., Wua X., Liua H., Chen Y. Thermal conductivity of powder silica hollow spheres. Thermochimica Acta, 2011, vol. 526, pp. 178-184.

13. Fiedler T., Löffler R., Bernthaler T., Winkler R., Belova I.V., Murch G.E., Öchsnerc A. Numerical analyses of the thermal conductivity of random hollow sphere structures. Materials Letters, 2009, vol. 63 (13-14), pp. 1125-1127.

14. Ryzhenkov A.V., Lapin E.E., Loginova N.A., Sitdikov D.R., Grigorev S.V. Evaluation of the thermal efficiency of a high- 
temperature heat-insulation structure based on honeycomb plastic. Thermal Engineering, 2016, vol. 63 (6), pp. 445-448.

15. Belyaeva E.V., Loginova N.A., Lapin E.E., Pogorelov S.I., Ryzhenkov A.V. Investigation of heat capacity of syntactic foam based on silicone and organic matrix. Oil Industry, 2016, no. 11, pp. 116-119.

16. Osipchik V.S., Kostromina N.V., Olikhova Y., Ivashkina V.N., Belyaeva E.V., Loginova N.A., Ryzhenkov A.V., Lapin E.E. Study of the influence of the modification of glass microspheres on the properties of syntactic foams based on oligomethylsiloxane. International Polymer Science and Technology, 2016, vol. 43 (7), pp. 133-137.

17. Levitin S.V., Belyaeva E.V., Loginova N.A., Lapin E.E., Ryzhenkov A.V. Study of relations components for making flexible polymer insulation with optimum thermal and mechanical characteristics. Oil Industry, 2015, no. 9, pp. 130-133.

18. Ryzhenkov A.V., Loginova N.A., Belyaeva E.V., Lapin Y.Y., Prischepov A.F Review of binding agents in syntactic foams for heat-insulating structures in power industry Facilities. Modern Applied Science, 2015, vol. 9, no. 4, pp. 96-105.

19. Polovnikov V.Y., Chuiko N.S. Heat transfer in layer of thin-film thermal insulation. AIP Conference Proceedings, 2019, vol. 2135, pp. 020045-1-020045-3.

Information about the authors
20. Kudryakov O.V., Varavka V.N. Integrated indentation tests of metal-ceramic nanocomposite coatings. Inorganic Materials, 2015 , vol. 51 , no. 15 , pp. $1508-1514$

21. Zhang Z. Nano/microscale heat transfer. New York, McGraw-Hill, 2007. $479 \mathrm{p}$.

22. Flik M., Choi B., Goodson K. Heat transfer regimes in microstructures. Journal Heat Transfer, 1992, vol. 114, pp. 667674

23. Bynum R.T. Insulation Handbook. New York, McGraw-Hill, 2001. $494 \mathrm{p}$.

24. Bejan A. Convection heat transfer. New York, Wiley, 2004. 696 p.

25. Garcia A.L. Numerical methods for physics. San Jose CA, CreateSpace Independent Publishing Platform, 2015. 432 p

26. Anisimov M.V., Lychagin D.V., Rekunov V.S., Taalaybekov Z.T. Experimental definition of integrated emissivity factor of ultrathin fluid composite heat insulating coatings. Bulletin of the Tomsk Polytechnic University. Geo Assets Engineering, 2016, vol. 327 (5), pp. 106-115. In Rus.

Received: 13 March 2020.

Viacheslav Yu. Polovnikov, Cand. Sc., associate professor, National Research Tomsk Polytechnic University. 